\title{
Antidiabetic Potential Screening of Ulin Fruit Extract (Eusideroxylon zwageri) Against Streptozotocin-Induced Diabetic Rats
}

\author{
Muhammad R. Faisal ${ }^{1}$, Nada W.O. Amanda ${ }^{1}$, Diana A. Mursidah ${ }^{1}$, Dede Mahdiyah ${ }^{2 *}$, \\ Bayu H. Mukti ${ }^{3}$ \\ ${ }^{1}$ Student of Pharmacy Undergraduate Study Program, Faculty of Health, Sari Mulia University, Banjarmasin, Indonesia \\ ${ }^{2}$ Pharmacy Undergraduate Study Program, Faculty of Health, Sari Mulia University, Banjarmasin, Indonesia \\ ${ }^{3}$ Biology Education Study Program, STKIP PGRI Banjarmasin, Indonesia \\ Submitted 16 November 2021; Revised 03 December; Accepted 03 December 2021; Published 30 December 2021 \\ *Corresponding author: mahdiyahmukti@gmail.com
}

\begin{abstract}
Empirical evidence of complementary medicine from one community in Kalimantan often uses Ulin fruit (Eusideroxylon zwageri) for medical therapy or as herbal drinks by people with diabetes mellitus. This research aims to identify the antidiabetic compound of Ulin fruit extract against Streptozotocin (STZ) induced diabetic rats. Extraction was performed by maceration method using $96 \%$ ethanol, phytochemical test of extracts, extract toxicity test on mice $(50 \mathrm{mg} / \mathrm{BW}$ to $200 \mathrm{mg} / \mathrm{BW})$, test antidiabetic extract in diabetic rats induced by STZ as much as $70 \mathrm{mg} / \mathrm{kgBW}$ with each extract dose of 150,300 , and $600 \mathrm{mg}$ given for 14 days, positive control is Glibenclamide $0.25 \mathrm{mg} / \mathrm{kg} /$ day, and the negative control is $\mathrm{CMC} 1 \%$. Phytochemical test results showed that the extract of Ulin contains alkaloids, tannins, flavonoids, phenolics, terpenoids, and steroids. Ulin fruit extract was not toxic to rats at 50,150, and $200 \mathrm{mg}$ for three days. Based on the Mann-Whitney test, there was an effect of giving the extract on changes in the average body weight and body temperature of rats during three days of administration $(\mathrm{p}=0.000)$. The results showed novelty that the extract of Ulin fruit affected reducing blood glucose levels in diabetic rats during 14 days of administration $(\mathrm{p}=0.000)$.
\end{abstract}

Keywords: Antidiabetic, Eusideroxylon zwageri, flavonoids, streprozotocin, diabetic rats

\section{Skrining Potensi Antidiabetes Ekstrak Buah Ulin (Eusideroxylon zwageri) Terhadap Tikus Diabetes yang Diinduksi Streptozotocin}

\begin{abstract}
Abstrak
Bukti empiris pengobatan tradisional salah satu masyarakat di Kalimantan sering menggunakan buah ulin (Eusideroxylon zwageri) untuk terapi medis atau sebagai minuman herbal oleh penderita diabetes mellitus. Penelitian ini bertujuan untuk mengidentifikasi senyawa antidiabetes ekstrak buah ulin terhadap tikus diabetes yang diinduksi Streptozotocin (STZ). Ekstraksi dengan metode maserasi menggunakan etanol 96\%, uji fitokimia ekstrak, uji toksisitas ekstrak terhadap tikus (50mg/BB sampai dengan 200mg/BB), uji antidiabetes ekstrak pada tikus diabetik yang diinduksi STZ sebanyak $70 \mathrm{mg} /$ $\mathrm{kgBB}$ dengan masing-masing dosis esktrak yaitu 150, 300, dan $600 \mathrm{mg}$ yang diberikan selama 14 hari, kontrol positif Glibenclamide $0,25 \mathrm{mg} / \mathrm{kg} /$ hari dan kontrol negatif CMC 1\%. Hasil uji fitokimia menunjukkan bahwa ekstrak buah ulin mengandung alkaloid, tanin, flavonoid, fenolat, terpenoid, dan steroid. Ekstrak buah ulin tidak bersifat toksik pada tikus pada dosis 50, 150, dan $200 \mathrm{mg}$ selama pemberian 3 hari. Berdasarkan uji Mann-Whitney, terdapat pengaruh pemberian ekstrak terhadap perubahan rerata berat badan dan suhu badan tikus selama pemberian 3 hari $(\mathrm{p}=0,000)$. Hasil uji menunjukkan kebaruan bahwa ekstrak buah ulin berpengaruh terhadap penurunan kadar glukosa darah tikus diabetes selama pemberian 14 hari $(\mathrm{p}=0,000)$.
\end{abstract}

Kata Kunci: Antidiabetes, Eusideroxylon zwageri, flavonoid, streprozotocin, tikus diabetes 


\section{Introduction}

Diabetes mellitus (DM) is a global health problem and has been increasing rapidly in both developed and developing countries. The International Diabetes Federation (IDF) estimates that around 415 million adults had diabetes in 2015, and the number of adults with DM in the world could increase to 642 million by $2040 .{ }^{1} \mathrm{DM}$ is a serious chronic and complex metabolic disorder of several etiologies with profound consequences, both acute and chronic. It is a metabolic disorder characterized by high blood glucose, high insulin production, high insulin resistance and glucose or insulin intolerance. There are two main forms of diabetes, insulin dependent diabetes mellitus (type 1 diabetes mellitus, T1DM) and non-insulin dependent diabetes mellitus (type 2 diabetes mellitus, T2DM). ${ }^{2}$

The World Health Organization (WHO) has also estimated that nearly 422 million people were affected with T2DM worldwide in 2014 and the condition will double by 2030. The prevalence of diabetes mellitus in Indonesia is $2.1 \%$. The highest prevalence of diabetes mellitus is at age $>15$ years. The highest prevalence of diabetes mellitus is Central Sulawesi (3.7\%), North Sulawesi (3.6\%) and South Sulawesi (3.4\%). While the lowest was in Lampung Province $(0.8 \%)$, then Bengkulu and West Kalimantan (1\%) and Central Kalimantan (1.5\%), and South Kalimantan (1\%). ${ }^{3}$

Many active fractions from plants with medicinal properties have been isolated and about $50 \%$ of pharmaceutical drugs are directly or indirectly derived from plants. Due to some limitations associated with the use of existing synthetic antidiabetic drugs, the search for newer antidiabetic drugs from natural sources continues. For centuries, many plants have been considered as basic sources of potent antidiabetic drugs. In developing countries, in particular, medicinal plants are used to treat diabetes. Natural products, especially those of plant origin, are the main source for finding promising prime candidates and play an important role in drug development programs. ${ }^{4}$

Pandit's research results stated that
Ficus religiosa bark extract showed significant antilipidperoxidative effect on the pancreas of Streptozotoxin-induced diabetic rats, Ficus religiosa bark extract had significant antidiabetic activity. ${ }^{5}$ In addition, the bark extract $(70 \%$ ethanol) from the Vatairea macrocarpa plant showed that long-term use of the $V$. macrocarpa bark extract could be helpful in treating diabetic conditions. ${ }^{6}$ The discovery of new drugs for diabetes mellitus is still being carried out and research is still ongoing in the scientific community around the world to evaluate the antidiabetic activity of raw materials or isolated natural products without side effects.

Ulin fruit is a fruit that grows on the Ulin Tree (Eusideroxylon zwageri) is widely used by the people of West and South Kalimantan as a herbal medicine to treat diabetes mellitus and heart disease, and empirical evidence from the people in West Kalimantan that Ulin fruit is often consumed by people with diabetes mellitus and heart disease and is proven to be effective. lowers blood sugar levels and also improves heart performance. Departing from this empirical evidence, researchers want to dig deeper into the potential of phytochemical compounds from Ulin fruit as antidiabetic. The purpose of this study was to identify the antidiabetic compound of ulin fruit extract (Eusideroxylon zwageri) against Streptozotocin (STZ) induced diabetic rats.

\section{Materials and methods}

2.1. Tools and materials

Ulin fruit used was taken from the Amuntai Tropical Forest with the specimen number 01 BU. Ulin fruit extract, $96 \%$ ethanol, wistar rats, salt, glucose, and streptozotocin. The tools used in this study were a socket, shaker, test tube, measuring flask, measuring cup, beaker, funnel, autoclave, volumetric pipette, and evaporator.

\subsection{Methods}

\subsubsection{Ulin Fruit Extraction Method}

Ulin fruits were extracted with solvents such as ethanol, methanol, hexane, petroleum ether using soxhlet apparatus. $20 \mathrm{~g}$ of sample was extracted using $200 \mathrm{~mL}$ of the above 
mentioned solvent for 6 hours. Using a rotary evaporator, the solvent evaporates under reduced pressure at $55^{\circ} \mathrm{C}$. The extract was prepared by dissolving $20 \mathrm{~g}$ of sample in 200 $\mathrm{mL}$ of water and incubated overnight in a shaker at $37^{\circ} \mathrm{C}$. The dry extract was used for further studies.

\subsubsection{Phytochemical Analysis}

Extract of Ulin Fruit were tested for the presence of active compound such as alkaloid, flavonoids, steroids, triterpenoids, phenolic, saponins, and tannins.

\subsubsection{Acute Toxicity Studies}

Acute oral toxicity studies were carried out according to the guidelines established by the OECD. The starting dose was chosen to be $200 \mathrm{mg} / \mathrm{kg}$ and finally the $500 \mathrm{mg} / \mathrm{kg}$ dose was evaluated for toxicity.

\subsubsection{Evaluation of Antidiabetic Ulin Fruit Extract \\ Rats were induced by intraperitoneal injection of Steptozotoxin (STZ) at a dose of $70 \mathrm{mg} / \mathrm{kg}$ body weight, dissolved in $0.1 \mathrm{M}$ cold citrate buffer $(\mathrm{pH}=4.5)$.}

\subsubsection{Chronic Rat Treatment Model}

Rats were divided into three groups each $(n=2)$. Group 1 served as control and untreated diabetes control, respectively. Group 2 served as the standard and was treated with $0.25 \mathrm{mg} / \mathrm{kg} /$ day of glibenclamide (Sun Pharmaceuticals Ltd.). Group 3 was given Ulin fruit extract at $500 \mathrm{mg} / \mathrm{kg}$ orally/ day for 14 days. Blood glucose levels were measured on days 1,7 , and 14 .

\subsubsection{Statistical analysis}

The data obtained were expressed as mean \pm mean standard error for the toxicity test and for antidiabetics determined by Kruskal Wallis and followed by the MannWhitney test.

\section{Result}

3.1. Phytochemical Analysis

Table 1 shows the screening results of phytochemical compounds from whole Ulin fruit extract (Eusideroxylon zwageri).

\subsection{Acute Toxicity Studies}

\subsubsection{Weight}

Based on Table 2 shows that the dose of ironwood extract (Eusideroxylon zwageri) $150 \mathrm{mg}$ has an effect on changes in the average body weight of wistar rats with $p$ value $=0.000$.

Based on Table 3 shows that the incubation period of 48 hours and 72 hours in the administration of ironwood extract to diabetic rats there was a significant difference with $p$ value $=0.001$.

\subsubsection{Body temperature}

Based on Table 4, it shows that the administration of concentrations (50, 100, 150 , and $200 \mathrm{mg}$ ) dose of Ulin fruit extract has an effect on changes in the average body temperature of rats given for 3 days.

Based on Table 5 shows that the incubation time of 24 hours and 48 hours has a significant difference $(p=0.004)$ to changes in the average body temperature of rats, 48 hours and 72 hours has a significant difference $(p=0.042)$ to changes in the average body

Table 1. Screening Results of Phytochemical Compounds from Whole Ulin Fruit Extract (Eusideroxylon zwageri)

\begin{tabular}{ccc}
\hline No. & Active Compounds from Whole Ulin Fruit Extract & Information \\
\hline 1 & Alkaloids & Positive \\
2 & Flavonoids & Positive \\
2 & Steroids & Positive \\
4 & Triterpenoids & Positive \\
5 & Phenolic & Positive \\
6 & Saponins & Positive \\
7 & Tannins & Positive \\
\hline
\end{tabular}


Table 2. Average Body Weight of Rats when Given Ulin Fruit Extract (Eusideroxylon zwageri) with Dosage 50, 100, 150, and $200 \mathrm{mg}$ for 3 Days

\begin{tabular}{cccc}
\hline Treatment & Extract Concentration & Mean \pm SD & P \\
\hline Control (CMC 0.1) & $50 \mathrm{mg}$ & $-0.77 \pm 2.83$ & 0.999 \\
& $100 \mathrm{mg}$ & $4.66 \pm 2.83$ & 0.477 \\
$150 \mathrm{mg}$ & $17.55^{*} \pm 2.83$ & 0.000 \\
$200 \mathrm{mg}$ & $3.44 \pm 2.83$ & 0.742 \\
$50 \mathrm{mg}$ & Control & $0.77 \pm 2.83$ & 0.999 \\
& $100 \mathrm{mg}$ & $5.44 \pm 2.83$ & 0.323 \\
& $150 \mathrm{mg}$ & $18.33^{*} \pm 2.83$ & 0.000 \\
\multirow{3}{*}{$100 \mathrm{mg}$} & $200 \mathrm{mg}$ & $4.22 \pm 2.83$ & 0.574 \\
& Control & $-4.66 \pm 2.83$ & 0.477 \\
& $50 \mathrm{mg}$ & $-5.44 \pm 2.83$ & 0.323 \\
& $150 \mathrm{mg}$ & $12.88^{*} \pm 2.83$ & 0.000 \\
$150 \mathrm{mg}$ & $200 \mathrm{mg}$ & $-1.22 \pm 2.83$ & 0.992 \\
& Control & $-17.55 \pm 2.83$ & 0.000 \\
& $50 \mathrm{mg}$ & $-18.33^{*} \pm 2.83$ & 0.000 \\
& $100 \mathrm{mg}$ & $-12.88^{*} \pm 2.83$ & 0.000 \\
$200 \mathrm{mg}$ & $200 \mathrm{mg}$ & $-14.11 \pm 2.83$ & 0.000 \\
& Control & $-3.44 \pm 2.83$ & 0.742 \\
& $50 \mathrm{mg}$ & $-4.22 \pm 2.83$ & 0.574 \\
& $100 \mathrm{mg}$ & $1.22 \pm 2.83$ & 0.992 \\
& $150 \mathrm{mg}$ & $14.11^{*} \pm 2.83$ & 0.000 \\
\hline
\end{tabular}

temperature of rats.

3.3. Antidiabetic from Ulin Fruit Extract (Eusideroxylon zwageri)

From the results of the data obtained for 14 days of administration of Ulin fruit extract (Eusideroxylon zwageri) with concentrations of $150 \mathrm{mg}, 300 \mathrm{mg}$, and $600 \mathrm{mg}$, it can be seen from Table 6 that blood glucose levels in rats decreased, which previously increased blood glucose levels in test animals. after being given a Steptozotocin compound intravenously. From the three concentrations, we can see that it is able to reduce blood sugar levels in rats. The results of statistical analysis with Mann Whitney showed that the duration of administration of Ulin fruit extract (Eusideroxylon zwageri) had an effect on decreasing blood glucose levels of diabetic wistar rats $(\mathrm{p}=0.000)$.

\section{Discussion}

Based on phytochemicals screening of Ulin fruit extract (Eusideroxylon zwageri), produced seven phytochemicals, namely Alkaloids, Flavonoids, Steroids,

Table 3. Effect of Ulin Fruit Extract Concentration (Eusideroxylon zwageri) on Changes in Rat Body Weight Based on Incubation Duration for 72 Hours

\begin{tabular}{cccc}
\hline Incubation period & Time & Mean \pm SD & P \\
\hline \multirow{2}{*}{24 hours } & 48 hours & $4.6 \pm 2.19$ & 0.097 \\
& 72 hours & $-4.3 \pm 2.19$ & 0.132 \\
48 hours & 24 hours & $-4.6 \pm 2.19$ & 0.097 \\
\multirow{2}{*}{72 hours } & 72 hours & $-9.0^{*} \pm 2.19$ & 0.001 \\
& 24 hours & $4.3 \pm 2.19$ & 0.132 \\
& 48 hours & $9.0^{*} \pm 2.19$ & 0.001 \\
\hline
\end{tabular}


Table 4. Average Body Temperature of Rats when Given Ulin Fruit Extract (Eusideroxylon zwageri) with Dosage 50, 100, 150, and $200 \mathrm{mg}$ for 3 Days

\begin{tabular}{cccc}
\hline Treatment & Extract Concentration & Mean \pm SD & P \\
\hline Control (CMC 0.1) & $50 \mathrm{mg}$ & $-0.25 \pm 0.09$ & 0.132 \\
$100 \mathrm{mg}$ & $-0.15 \pm 0.07$ & 0.356 \\
$150 \mathrm{mg}$ & $0.12 \pm 0.08$ & 0.600 \\
$200 \mathrm{mg}$ & $0.17 \pm 0.08$ & 0.314 \\
$50 \mathrm{mg}$ & Control & $0.25 \pm 0.09$ & 0.132 \\
& $100 \mathrm{mg}$ & $0.10 \pm 0.07$ & 0.707 \\
& $150 \mathrm{mg}$ & $0.38^{*} \pm 0.08$ & 0.007 \\
\multirow{3}{*}{$100 \mathrm{mg}$} & $200 \mathrm{mg}$ & $0.42^{*} \pm 0.08$ & 0.003 \\
& Control & $0.15 \pm 0.07$ & 0.356 \\
& $50 \mathrm{mg}$ & $-0.10 \pm 0.07$ & 0.707 \\
& $150 \mathrm{mg}$ & $0.28^{*} \pm 0.06$ & 0.010 \\
$150 \mathrm{mg}$ & $200 \mathrm{mg}$ & $0.32^{*} \pm 0.06$ & 0.002 \\
& Control & $-0.12 \pm 0.08$ & 0.600 \\
& $50 \mathrm{mg}$ & $-0.38^{*} \pm 0.08$ & 0.007 \\
& $100 \mathrm{mg}$ & $-0.28^{*} \pm 0.06$ & 0.010 \\
$200 \mathrm{mg}$ & $200 \mathrm{mg}$ & $0.04 \pm 0.07$ & 0.973 \\
& Control & $-0.17 \pm 0.08$ & 0.314 \\
& $50 \mathrm{mg}$ & $-0.42^{*} \pm 0.08$ & 0.003 \\
& $100 \mathrm{mg}$ & $-0.32^{*} \pm 0.06$ & 0.002 \\
& $150 \mathrm{mg}$ & $-0.04 \pm 0.07$ & 0.973 \\
\hline
\end{tabular}

Triterpenoids, Phenolics, Saponins, and Tannins. A phytochemical screening test is helpful for early detection of active compounds and as an early picture in starting drug search and development, especially for antidiabetic. Due to the presence of seven phytochemicals in Ulin fruit extract (Eusideroxylon zwageri), it can be used as an initial screening to see antidiabetic activity in diabetic rats induced by streptozotocin.

One of the natural compounds as antidiabetic producers is flavonoids. ${ }^{7}$ Flavonoids are an important class of natural products; in particular, they belong to a class of plant secondary metabolites having a polyphenolic structure, found abundantly in certain fruits, vegetables and beverages. They have various beneficial biochemical and antioxidant effects associated with various diseases such as cancer, Alzheimer's disease (AD), atherosclerosis, diabetes, and others. ${ }^{8}$

Based on the other research, apigenin plays an antidiabetic role $^{9}$ mainly through signalling pathways that work in small islets and peripheral tissues. For example, apigenin may protect-cell function by inhibiting

Table 5. Effect of Ulin Fruit Extract (Eusideroxylon zwageri) on Changes in Body Temperature of Rats Based on Incubation Time for 72 hours

\begin{tabular}{cccc}
\hline Incubation period & Time & Mean \pm SD & P \\
\hline \multirow{2}{*}{24 hours } & 48 hours & $-0.23^{*} \pm 0.05$ & 0.004 \\
\multirow{2}{*}{48 hours } & 72 hours & $-0.07 \pm 0.05$ & 0.411 \\
& 24 hours & $0.23^{*} \pm 0.05$ & 0.004 \\
\multirow{2}{*}{72 hours } & 72 hours & $0.16^{*} \pm 0.05$ & 0.042 \\
& 24 hours & $0.07 \pm 0.05$ & 0.411 \\
& 48 hours & $-0.16^{*} \pm 0.05$ & 0.042 \\
\hline
\end{tabular}


inflammatory signalling pathways, further suggesting that inflammatory signalling pathways may be a novel therapy. Target the antidiabetic effect of apigenin, which needs further investigation. Apigenin can also increase peripheral insulin sensitivity and promote insulin resistance and abnormal lipid metabolism, which is achieved mainly through modulation of AMPK activity and related gene expression and miRNA regulation. ${ }^{10}$

Secondary metabolites (phytochemicals) and other chemical constituents of medicinal plants explain their medicinal value. For example, saponins have hypotensive and cardio depressant properties. ${ }^{11}$ The presence of saponins in whole Ulin fruit extract may play a role in its cardioprotective potential. ${ }^{12}$ Based on research Bhandary et al. stated that three different extracts of whole fruit (Punicia granatum) were found to contain Triterpenoids, Steroids, Glycosides, Saponins, Alkaloids, Flavonoids, Tannins, Carbohydrates \& Vitamin C. ${ }^{13}$

This study was conducted to evaluate the toxicity of Ulin fruit extract and its effect on STZ-induced diabetic rats. The results indicated that no signs of toxicity from the Ulin fruit extract that was given, starting from a dose of $50 \mathrm{mg} / \mathrm{bb}$ to a dose of $200 \mathrm{mg} /$ $\mathrm{bb}$ rats. It can be seen from the average body weight of rats and the body temperature of rats, which are stable and there is no decrease, and there is no morbidity or injury in rats. In testing the antidiabetic activity of Ulin fruit extract on rats, it showed that when induced with STZ, rats blood glucose levels were $200 \mathrm{mg} / \mathrm{dL}$ for all treatments (this indicates diabetes). After being given the extract on the first day, there was still an increase in rat blood glucose levels. On the seventh day, there was a decrease in the rats blood glucose levels until the 14th day. The rats blood glucose levels decreased and were stable, and they did not experience diabetes anymore. Provides evidence that Ulin fruit extract may contain hypoglycemic compounds. Phytochemical compounds of Ulin fruit extract have shown the presence of tannins, flavonoids known for their hypoglycemic activity. ${ }^{14}$ Plants can exert their action by increasing the proliferation or renewal of islet cells after destruction by streptozotocin. It was amplified by the strong immunostaining of mouse islet cells treated with plant extracts. ${ }^{15}$

It is known that streptozotocin acts by damaging cells; ${ }^{16}$ so that plant extracts can act in these conditions by increasing peripheral glucose uptake. In streptozotocin-induced diabetic mice, the reduction was moderate but significant. Reported that glibenclamide was ineffective when it destroyed cells. ${ }^{17}$ In our study, glibenclamide induced a significant decrease in blood glucose levels in streptozotocin-induced diabetic rats exhibiting partial destruction of pancreatic cells. This is in line with the results of previous studies as revealed by Alotaibi et al. According to Alotaibi et al., the effect of gilbenclamide on

Table 6. Antidiabetic Activity of Ulin Fruit Extract Against Streptozotoxin-induced Diabetic Rats

Blood Glucose (mg/dL)

\begin{tabular}{ccccccc}
\cline { 2 - 5 } Treatment & $\begin{array}{c}\text { Before } \\
\text { Induced } \\
\text { STZ }\end{array}$ & $\begin{array}{c}\text { After } \\
\text { Induced } \\
\text { STZ }\end{array}$ & Day 1 & Day 7 & Day 14 & P \\
\hline Negative control & 92 & 200 & 250 & 496 & 403 & \\
$\begin{array}{c}\text { Positive control } \\
150 \text { mg Extract Ulin }\end{array}$ & 74 & 200 & 113 & 78 & 85 & \\
$\begin{array}{c}\text { Fruits } \\
300 \text { mg Extract Ulin }\end{array}$ & 77.5 & 200 & 354.5 & 100 & 73 & $0.000^{*}$ \\
$\begin{array}{c}\text { Fruits } \\
600 \text { mg Extract Ulin } \\
\text { Fruits }\end{array}$ & 70 & 200 & 246.5 & 99 & 86 & \\
\hline
\end{tabular}

*Mann Whitney Test 
lowering glucose levels in serum was induced by NA-STZ induced diabetic rats. ${ }^{18}$

Streptozotocin induces an increase in triglycerides, total cholesterol, LDLcholesterol, atherogenic index and lowers HDL cholesterol. Hypertriglyceridemia and hypercholesterolemia are the main factors of diabetes involved in developing atherosclerosis and coronary heart disease, which is a secondary complication of diabetes, ${ }^{19}$ However, in our study, we have not tested cholesterol levels. We also believe due to the phytochemical studies was done previously. ${ }^{20}$ The phytochemical test showed the presence of alkaloid compounds in which these compounds function to overcome arrhythmias, ${ }^{21}$ also contain flavonoid compounds that prevent heart disease. ${ }^{22}$

These results prove the hypothesis that plant extracts have antidiabetic activity as in the $\operatorname{study}^{23}$ rats induced by diabetes showed a significant decrease in blood glucose and triglycerides $(\mathrm{p}<0.05)$ after being given the ethanolic extract of Sphagnelicola trilobata flowers for 14 days. In addition, Florence et al. showed that the Annona muricata plant had antidiabetic against STZ-induced diabetic rats during 28 days of administration. ${ }^{24}$ Based on the other study, Carissa carandas Linn. fruit extract showed that the methanol extract and its ethyl acetate soluble fraction significantly reduced the increase in blood glucose levels by $48 \%(p<0.001)$ and $64.5 \%(p<0.001) .{ }^{25}$

\section{Conclussion}

Ulin fruit extract can be used as an antidiabetic drug because it is not toxic, it is proven in the results that the extract is safe to use starting at doses of $50 \mathrm{mg}-200 \mathrm{mg}$. Ulin fruit extract also had antidiabetic against STZ-induced diabetic rats during 14 days of administration with doses of $150 \mathrm{mg}, 300$ $\mathrm{mg}$, and $600 \mathrm{mg}$. Based on statistical analysis with Mann Whitney showed that there were significant differences in each dose of Ulin fruit extract in reducing blood glucose levels in diabetic rats $(\mathrm{P}=0.000)$.

\section{Acknowledgement}

We would like to thank the Directorate of Learning and Student Affairs, Ministry of Education and Culture, Research Technology and Higher Education for funding the Student Creativity Program grant, 2021, the Exact Research scheme.

\section{References}

1. Zhang L, Liu Y, Ke Y, Liu Y, Luo X, $\mathrm{Li} \mathrm{C}$, et al. Antidiabetic activity of polysaccharides from Suillellus luridus in streptozotocin-induced diabetic mice. Int J Biol Macromol. 2018; 119: 134-140.

2. Wu Y, Ding Y, Tanaka Y, Zhang W. Risk Factors Contributing to Type 2 Diabetes and Recent Advances in the Treatment and Prevention. Int J Med Sci. 2014;11(11):1185-200.

3. Badan Penelitian dan Pengembangan Kesehatan. Riset Kesehatan Dasar (RISKESDAS) 2013. Lap Nas 2013. 2013;1-384.

4. Koehn F, Carter G. The evolving role of natural products in drug discovery. Nat Rev Drug Discov. 2005;4:206-20.

5. Pandit R, Phadke A, Jagtap A. Antidiabetic effect of Ficus religiosa extract in streptozotocin-induced diabetic rats. J Ethnopharmacol. 2010;128:462-6.

6. Oliveira H, Santos Mp, Grigola R, Lima L, Martins D, Lima J, et al. Antidiabetic activity of Vatairea macrocarpa extract in rats. J Ethnopharmacol. 2008;115:515-9.

7. Ullah A, Munir S, Badshah S, Khan N, Ghani L, Poulson B, et al. Therapeutic Agent. Molecules. 2020;25(5243):1-39.

8. Panche A, Diwan A, Chandra S. Falvonoids: an overview. J Nutr Sci. 2016;5(47):1-15.

9. Osigwe C, Akah P, Nworu C, Okoye F. Apigenin: A methanol fraction component of Newbouldia laevis leaf, as a potential antidiabetic agent. J Phytopharm. 2017;6(1):38-44.

10. Salehi B, Ata A, Kumar N, Sharopov F, Ram K, Ruiz-ortega A, et al. Antidiabetic Potential of Medicinal Plants and Their Active Components. Biomolecules. 2019;9(551):1-121.

11. Olaleye M. Cytotoxicity and antibacterial activity of methanolic extract of Hibiscus 
sabdariffa. J Med Plants Res. 2007;1:913.

12. Brian F, Thomas-Bigger J, Goodman G. The Pharmacological Basis of Therapeutics. Macmillan, New York: NY, USA.; 1985. 7 p.

13. Bhandary SK, N SK, Bhat VS, Sharmila KP, Bekal MP. Preliminary phytochemical screening of various extracts of Punica granatum peel, whole fruit and seeds. 2020;2(4).

14. Ojewole J. Antinociceptive, antiinflammatory and antidiabetic effects of Bryophyllum pinnatum (Crassulaceae) leaf aqueous extract. J Ethnopharmacol. 2005;99:13-19.

15. Miranda-Osorio PH, Castell-Rodríguez AE, Vargas-Mancilla J, Tovilla-Zárate CA, Ble-Castillo JL, Aguilar-Domínguez $\mathrm{DE}$, et al. Protective action of Carica papaya on $\beta$-cells in streptozotocininduced diabetic rats. Int $\mathrm{J}$ Environ Res Public Health. 2016;13(5).

16. SzkudelskiT, SzkudeskaK. Streptozotocin induces lypolysis in rat adipocytes in vitro. Physiol Res. 2002;51:255-259.

17. Hosseinzadeh H, Ramezani M, Danael A. Antihyperglycaemic effect and acute toxicity of Securigera securidaca L. seed extracts in mice. Phyther Res. 2002;16:745-747.

18. Alotaibi MR, Fatani AJ, Almnaizel AT, Ahmed MM, Abuohashish HM, Al-Rejaie SS. In vivo Assessment of Combined Effects of Glibenclamide and Losartan in Diabetic Rats. Med Princ Pract. 2019;28(2):178-185.

19. Ananthan R, Latha M, Ramkumar K, Pari L, Baskar C, Bai V. Effect of Gymnema montanum leaves on serum and tissue lipids in alloxan diabetic rats. Exp Diabetes Res. 2003;4:183-189.

20. Kusuma IW, Rahmini, Ramadhan R, Rahmawati N, Suwasono RA, Sari NM. Phytochemicals and antidiabetic activity of Eusideroxylon zwageri stem bark collected from East Kalimantan, Indonesia. IOP Conf Ser Earth Environ Sci. 2018;144(1).

21. J. Boratyński P, Zielińska-Błajet M, Jacek
S. Cinchona Alkaloids-Derivatives and Applications. In: The Alkaloids: Chemistry and Biology. Elsevier Inc.; 2019. p. 29-145.

22. CLM, Q D, CN. Blesso. Effects of Dietary Flavonoids on Reverse Cholesterol Transport, HDL Metabolism, and HDL Function. Adv Nutr. 2017;15(8):226-239.

23. Buddhakala N, Talubmook C. Toxicity and antidiabetic activity of ethanolic extract of Sphagneticola trilobata (L.) Pruski flower in rats. J Ethnopharmacol. 2020;262(15):113-128.

24. Florence N, Benoit M, Jonas K, Alexandra T, Désiré D, Pierre K, et al. Antidiabetic and antioxidant effects of Annona muricata (Annonaceae), aqueous extract on streptozotocin-induced diabetic rats. J Ethnopharmacol. 2014;151:784-790.

25. Itankar P, Lokhande S, Verma P, Arora S, Sahu R, Patil A. Antidiabetic potential of unripe Carissa carandas Linn. fruit extract. J Ethnopharmacol. 2011;135(2):430-3. 